Октавија И. Неделку ${ }^{I}$

УДК 82:929 Обреновић Н.

Универзитет у Букурешту ${ }^{2}$

https://doi.org/10.46630/ish.7.2021.14

Факултет за стране језике и књижевности

Департман за руску и словенску филологију

Лидија В. Чолевић

Универзитет у Букурешту

Факултет за стране језике и књижевности

Департман за руску и словенску филологију

\title{
КАД ПОРАСТЕМ БИЋУ КРАЉИЦА: НАТАЛИЈА И МИЛАН ОБРЕНОВИЋ
}

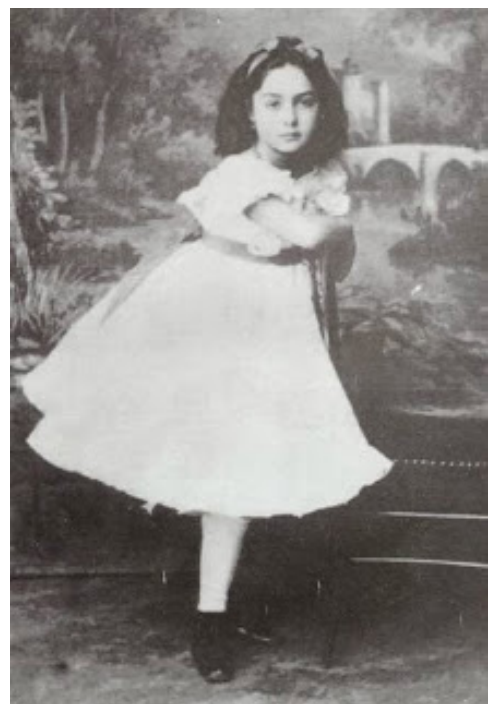

Портрет Наталије као десетогодишње девојчице (1869)

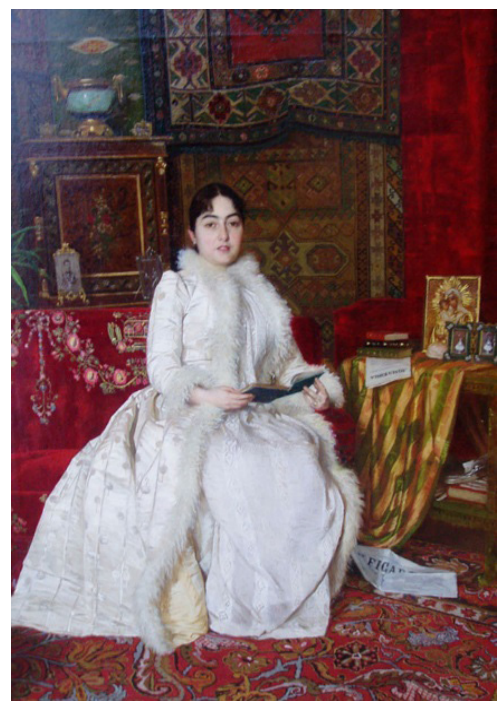

Краљица Наталија Урош Предић (1890)

На трагу новог историзма сагледавање односа историјске и уметничке стварности, визуелне културе и уметности, историографских и литерарних представа о краљици Наталији Обреновић, помаже у раслојавању многобројних улога које је она имала у српској култури. Културно-историјске релације краља Милана и краљице Наталије Обреновић, као део укупних међусобних

\footnotetext{
${ }^{1}$ octavia.nedelcu@lls.unibuc.ro, lidija.colevic@1ls.unibuc.ro

${ }^{2}$ Рад је настао у оквиру пројекта Истраживағе културе и историје Срба у Румунији који спроводи Центар за научна истраживања културе Срба у Румунији.
} 
веза српске и румунске културе су неоспорно неодвојиви део румунског идентитета.

Кључне речи: нови историзам, књижевно-историјски лик, краљица Наталија Обреновић, краљ Милан Обреновић IV, краљ Александар Обреновић, румунски идентитет.

Јубилеји какви су 80-годишњица од смрти Наталије Обреновић (1859$1941)^{3}$ или 120-годишњица од смрти Милана Обреновића (1854-1901)4 прилике су за разнолика преиспитивања династичких веза у оквиру српско-румунског културног трансфера.

Циљ је портрета и уопште визуелних јединица у нарацији ухватити истински изглед унутрашње личности повезан са њеним пуним идентитетом, али и преместити причу из медија у медијум. Иако су наратив и портрет у суштини различити културни изрази, активирањем визуелних наратива остварује се тзв. „трансмедијална флуидност”, па кроз репрезентативни портрет краљице Наталије, Уроша Предића из 1890. године, откривамо владарку и аристократкињу у раскошној хаљини, окружену традиционалним симболима статуса, православља и завичаја као невербалним знацима културе.

„Кад порастем бићу краљица” („Voi creşte mare și voi fi regină”) биле cy речи Наталије Кешко (Natalia Keșco) од милоште зване „госпођица Дуду”, чији се сан испунио са 16 година удајом за кнеза Милана Обреновића 1875. године. Идентитетско упориште од најранијег детињства илуструје портрет Наталије као десетогодишње девојчице из 1869. године. Звање краљице Наталија је носила од 1882. до 1888. године, када се развела од краља Милана. Упркос нередима на београдским улицама Наталија је 18. маја 1891. године, под притиском, „опкољена са свих страна полицијом, а брањена народом”, ипак удаљена из Србије. Доселила се у вилу у Бијарицу, у бањско лечилиште на француској обали Атлантика, коју је по сину Александру, назвала „Сашино”. Управо у тој вили је Наталијин син, будући престолонаследник Александар, упознао мамину пратиљу и дворску даму, удовицу Драгу Машин, своју будућу супругу и српску краљицу.

Књижевник Драгутин Илић у Роману краљище Наталије: Одломщи

\footnotetext{
${ }^{3}$ Наталија Обреновић умрла је у окупираној Француској, у Паризу 5. маја 1941. године и сахрањена је у Лардију (Lardy) где и данас почивају њени остаци. Четири деценије надживела је свог бившег супруга Милана Обреновића.

${ }^{4}$ Милан Обреновић умро је у Бечу где је емигрирао 1901. године. Сахрањен је у манастиру Крушедол на Фрушкој гори.

${ }_{5}^{5}$ Видети поглавља: Pictorial narrativity (стр. 430-435); Interdisciplinary approaches to narrative; (стр. 250-253) и Visual narativity (стр. 629-633); у Routledge Encyclopedia of Narrative Theory, Edited by David Herman, Manfred Jahn and Marie-Laure Ryan, Routledge, 2005.
} 
из дневника $(1923)^{6}$ успео је да читаоцу приближи вредну историјску грађу о Србији између два века и посведочи о родбинским и пријатељским везама краљице Наталије. Краљица Наталија Обреновић је лично познавала Илића и били су у контакту десетак година, те није необично што писац у својој прози наглашава епизоде у којима су им се животне стазе непосредно укрштале. Аутор је у улози савременика и Наталијиног „сапатника” описао своју улогу у организовању побуне народа ради одбране краљице и спречавању њеног протеривања из Србије. Илић пише директно, отворено, саопштавајући догађаје из сопствене визуре, коментаришући политичке прилике, могућа решења одређених ситуација, а оно што је интересантно, упоредо са тим доноси и мишљење јавности.

У раду су историјски ликови краљице Наталије и краља Милана сагледани из угла новог историзма, из аспекта партиципације литературе и најразличитијих некњижевних текстова у историјским процесима и односима. У томе нам осим бројних историографских извора, помажу путописи, мемоари, дневници, биографије, аутобиографије, историјске драме, политички списи, хроника европске штампе, али и илустративни материјал (фотографије, портрети, карикатуре) који је такође жанр сведочења.

Историографски извори у Румунији потврђују чињеницу да је Србија у 19. и 20. веку имала три крунисане краљице: Наталију Обреновић, Драгу Обреновић и Марију Карађорђевић ${ }^{7}$, од којих су две биле Румунке. И Наталија и Марија су прихватиле Србију као своју нову домовину уживајући огромно поштовање од стране српског народа (Catana, 2013: 22).

Наталијина оданост земљи, коју је сматрала својом, ишла је до хероизма, због чега је српски народ волео. У духу православне традиције показала је истинску побожност, спремност на свако пожртвовање и опште је позната честитост њеног приватног живота. Материјално је помагала српском народу у балканским ратовима. Током првих десет година свог брака и боравка у Србији Наталија је доживела најпре рат са Турском 1876-1878, а затим и рат са Бугарском 1885. године ${ }^{8}$, у којем је дошло до пораза српске војске. Истрошена Србија након неуспелих ратних потеза краља Милана постала јој је још ближа и ова тврдња стиче легитимитет у њеној исповести Драгутину Илићу у путопису о Румунији: „Да, Ви волете Србију своју; и она је мученица! Рекох ја. И како! И зашто да је не волем када ми она није

\footnotetext{
${ }^{6}$ Роман краљиие Наталије: Одломии из дневника излазио је са повременим прекидима од марта до маја 1923. у „Београдском дневнику” и сведочи о догађајима који су се збили 35 година раније, како их је лично доживео Драгутин Илић.

${ }^{7}$ Марија Карађорђевић (1900-1961) била је ћека румунског краља Фердинанда и супруга Александра Карађорђевића (1888-1934), краља Југославије.

${ }^{8}$ На интервенцију Аустро-Угарске, Бугарска је пристала на примирје. Мировни уговор је потписан фебруара 1886. године у Букурешту, по приципу status quo ante bellum, без икаквих других обавеза.
} 
ни зашта крива; ми обе страдамо од једнога демона". У прилог Наталијине племенитости говори и чињеница да је у току Првог светског рата неговала српске рањенике у својој вили „Сашино” у Бијарицу.

Увидом у вредна сведочанства на страним језицима о оновременим дипломатским, културним, политичким и друштвеним збивањима у Србији наилазимо на сличне наводе о краљици Наталији: „Затекао сам Србе подвојене по свим питањима унутрашње и спољне политике. Видео сам их сложне само у једној ствари: одушевљени су својом краљицом Наталијом” (...) „Била је добра вила српског народа и добар дух кнеза докле год ју је овај неуротични, нажалост, и натмурени кнез слушао" (Léger, 1967: 119). Још један, пажње вредан, осврт на краљицу Наталију пружа принц Хабсбург (Rudolf de Habsburg):

„Краљица Наталија нема ни нарав ни понашање краљице; Она је елегантна жена, која необично много улаже у тоалете и накит и воли да се дотера; Међутим, она се бори да је воле у земљи и избегава да учествује у расправама њеног супруга о недостацима Срба; Занима је војска, о којој са задовољством говори. Може се лако закључити да она воли Србију више од краља и више се занима за српски народ” (Lukács, 2013: 87).

За разлику од Наталије, за Милана Обреновића стиче се утисак да се мало држао постулата православног хришћанства. Сматрао је да му положај налаже формално поштовање црквеног церемонијала, према којем је у суштини био крајње индиферентан 9 .

Историјска методологија је стални пратилац модерних књижевно-научних истраживања, с тим да је реч о варијабилној и динамичкој категорији. У интерпретацији књижевног текста легитимно право сваког интерпретатора је узимање у обзир трију аспеката присуства историје: историјски приступ може да се сведе на биографизам, односно описивање историјских садржаја, те бављење тзв. „историјском филологијом дела”; историографски приступ проучава начине трансформације историјских реалија у књижевном тексту, поетичке, жанровске и интертекстуалне принципе кодирања историјских садржаја; исторични приступ проучава херменеутику текста и подразумева отвореност и динамизам различитих могућих интерпретација те доминантно обележје књижевног текста постаје велики број смислова (Милутиновић, 2007: 409-420).

Историја није више затворена и завршена књига чијим се прелиставањем бави историчар, већ је facta ficta. У овом сагледавању односа између

\footnotetext{
9 У прилог оваквој тврдњи стоје бројне афере са црквом у време Миланове владавине, смењивање Митрополита Михаила 1881. јер је био русофил, увођење црквених такси, непоштовање црквених канона и закона, уплитање у црквена питања и мењања надлежности без консултовања са црквеним великодостојницима и сл. По мишљењу Слободана Јовановића „Михаилов пад је означавао победу Аустрије на Балкану. Русија и пре овог догађаја није била задовољна кнезом Миланом и његовом аустрофилском политиком, те је стално потенцирала враћање Митрополита како би се тим чином Милан покајао и вратио православљу, а кроз православље словенској идеји и самој Русији" (Јовановић, 1990: 99).
} 
чињеничне, искуствене и фикционалне приповедне равни „ниједан дискурсфиктивни или архивски не изражава стварну људску природу” (Bužinjska, 2009: 558-562). На трагу новог историзма уочене су нагле промене вредности и интереса једног текста који је увек и културно и социјално условљен. Потврђује се став да су у 21. веку у студије књижевности инкорпориране студије културе где су визуелност и медијалност постали незаобилазни у тумачењу књижевног текста. Модел историје као емпиријске и позитивистичке друштвене науке која је претендовала на могућност проналажења и објективног саопштавања чињеница из прошле реалности, сменило је проблематизовање дејства доказа.

Као покровитељ уметности, моде и добротворних свечаности, краљица Наталија је у друштвено-историјском процесу женске еманципације одиграла радикално модернизаторску улогу. Била је еманципована у погледу образовања, јавног деловања и политичких и личних права и слобода, али и велики заговорник очувања култа женствености и мајчинства. Еманципаторска тенденција у оквиру једног новог јавног простора и свест о неминовности друштвене ангажованости уочена је у Наталијиној потреби да оснује „Женско друштво” у Београду и редефинише женски идентитет који подразумева жену еманциповану у сваком погледу.

Страни посматрачи, угледни уметници и научници који су се бавили проучавањем прилика у српској краљевини и њеној значајној улози на Истоку уверљиво сведоче да је дворски живот онога времена имао снажан источњачки карактер. Феликс Филип Каниц присећа се да у овом периоду жена излази из чисто породичне сфере, постаје образована, самостална и политички ангажована. Он подсећа на постојање „Наталијине улице” која се пружала између Скупштине града Београда и Извршног већа СРС, а која је срушена крајем 1903. године" (Kanitz, 1967: 244). Херберт Вивијен одушевљавао се „Наталијиним колом” које се радо играло на Београдским баловима (Vivian, 1967: 169).

Значајни историографски извори као што су: Влада Милана Обреновића (1934) Слободана Јовановића, Краљ Милан и жене (1925) Владимира Ћоровића или Споменица Њ.В. Краљице Наталије и др., указују на низ тема и мотива који су доминантни и надвладавају саму историјску основу, те захтевају анализу како из перспективе књижевног дела, тако и из угла културноисторијског сведочанства. Проширењем домена књижевности, смештањем књижевног дела у историјски контекст, ретроградира се поредак књижевног канона и тиме помаже фокусирање пажње на маргинализоване артефакте.

Поставља се питање у којој мери су текстуални трагови које нам је оставила прошлост поуздани оријентири транспозиције историје у књижевно дело. Статус Наталије и Милана Обреновића у српској ретроспективној библиографији и књижевној историји је у зависности од симпатија према краљи- 
ци или краљу врло шаролик. Обилује супротношћу судова када су ове личности у питању, што се и дало очекивати, имајући у виду дијаметралне разлике између основних књижевних стремљења у различитим историјским периодима. Понекад аутори делују у потпуно различитим околностима стварајући у временима сасвим некњижевним и непогодним за литерарне активности.

Попис дела који пружају увид у историјску прошлост и културну историју за време владавине династије Обреновића, нарочито Наталије и Милана, а затим и Александра, не претендује да буде апсолутно целовит и да донесе пресудне закључке, али верујемо да може представљати добар и користан материјал за детаљнија истраживања периода који је обележен бројним скандалима, аферама и турбуленцијама.

Кратак осврт на књижевну заоставштину Наталије Обреновић, Ружа и трюе ${ }^{10}$ показује да историја умногоме не оспорава истину, али је врло често обликује у контексту много ширем од контекста и живота једне личности. Мемоарска проза којој је посветила већи део свог живота у изгнанству, има историјски, књижевни и политички значај. Иако је била радо читана и превођена списатељьия, њени књижевни радови део су прећутане, игнорисане и омаловажене историје српске кьижевности.

Краљииа Наталија је на почетку брака са Миланом била романтична жена и веома заљубљена у свог супруга. То потврђују управо њени Мемоари у којима је записала:

„Три пута сам се видела са кнезом Миланом. Налазила сам да је леп момак, мада ми се његов глас није допао, али та појединост ме није зауставила и кад је затражио моју руку пристала сам сва срећна, осећајући да сам спремна да му дам и срце и душу! Сањала сам чаробан сан и била сам врло заљубљена у свог вереника" (Обреновић, 1999: 68).

Само годину дана након удаје за Милана, Наталија је родила Александра (1876-1903), наследника српског престола. У историји српског монархизма новог доба засигурно не постоји трагичнија личност него што је то био краљ Александар Обреновић (1893-1903).

После абдикације Милана Обреновића 1889. у корист тада још малолетног Александра, у Србији је успостављено Намесништво које је преузело надлежности из домена вршења краљевске власти. Милан ће издејствовати замашну суму новца и заузврат се одрећи српског држављанства, да би се затим настанио у Паризу као „кнез од Такова”. Међутим, бивши краљ ипак се враћао у Србију намећући се као важан политички фактор након што је његов син Александар 1893. године извршио државни удар, збацио Намесништво, и преузео власт у Србији. Према извору „краљ Милан је приспео у

\footnotetext{
${ }^{10}$ Књижевно дело краљице Наталије сабрано у издању Ружа и трње, у књизи коју су Љубинка Трговчевић, Светлана Томић и Ивана Хаџи-Поповић приредиле и објавиле 2015. године, обухвата Наталијину књижевну заоставштину: мемоарску прозу „Моје успомене” објављене 1891, бајке „Мати и син” настале 1892. године и афоризаме из 1897. године, као и бројну преписку.
} 
Србију октобра 1897. и наредне три године био је главни саветник сина, а по многима и његов савладар" (Рајић, 2013: 248).

Материнство је било извор Наталијине друштвене моћи, што потврђују бројни извори, домаћи и страни. Као врховни државни ауторитет, а уз то специфично женски, лик владарке који је потенциран кроз улогу мајке и мајчинства, сведочи о вишедимензионалности конзервативног и традиционалистичког дискурса у Србији у 19-ом веку.

„Једна мајка донесе на свет лепог дечака који је у њеном загрљају цветао као нежни пупољак руже. Мајка га миловаше, јер он беше читава њена срећа. Због велике љубави мишљаше да он није као остала деца, већ анђелак којег сам Бог посла да је утеши. Али док беше сва обузета радошћу, он преживи догађаје који јој сломише срце" (Обреновић, 2015: 75).

Неке од најизразитијих краљичиних особина које су помињали и српски и румунски савременици и биографи, знаменити српски историчар Слободан Јовановић сажео је у тврдњи: „Наталија се показала бољом као мати него као жена" (Јовановић, 1934: 366). И Драгутин Илић често се позива у својим текстовима на улогу Наталије као „мајке, супруге, владарке и интелектуалке”. Његове Успомене из Румуније „из бележника емигранчевог” (1904/1905) говоре о краљици Наталији као „страдалници, изгнанику и мученици”. Аутор ју је сместио у историјске оквире живота несрећних српских владарки које се нису могле похвалити брачном верношћу својих супруга.

С друге стране, вредно је присетити се да је новинар, књижевник и политичар, Пера Тодоровић (1852-1907), градећи краљев портрет у Успоменама на краља Милана (1903), приказао српског владара кроз фигуру „краља страдалника, мученика и жртвеника". Аутор правда краљеве слабости (колебљив карактер, несталност, манипулативност, плаховитост и ћудљивост) бројним атентатима на њега ${ }^{11}$ и превртљивошћу народа. Ево како је Тодоровић доживео краља:

„Имао си душу обилну добротом и срце богато љубављу и често си оберучке сејао милосрђе, па опет где год да си ногом стао, за тобом је изницало оштро трње мржње и тешке незахвалности. Много си радио и много урадио, али си био човек, а не анђео, и у твојим човечанским делима било је и човечанских погрешака" (Тодоровић, 1997б: 126).

Са пуно глорификације Тодоровић пише и о краљу Александру у делима: Српска ствар у Старој Србији: Успомене на краља Милана ${ }^{12}$, Олледало (1903) и Силазак с престола (1889-1891).

\footnotetext{
${ }^{11}$ Бројни атентати на краља Милана Обреновића, а нарочито Ивањдански атентат који се одиграо 6. јула 1899. узбудили су европску јавност. Припреме за атентат одигране су у великој мери у румунским центрима руске обавештајне службе. Видети: Andrija Radenić, Progoni političkih protivnika u režimu Aleksandra Obrenovića 1893-1903. Beograd: Istorijski arhiv Beograda 1973.

${ }^{12}$ Дело Српска ствар у Старој Србији: Успомене на краља Милана излазило је у наставцима 1901. у часопису Мале новине три месеца после краљеве смрти.
} 
Након развода са Наталијом, углед краља Милана, као и углед целе династије страдао је не само у патријархалној Србији, већ је овај скандал нашао одјека и у високим политичким круговима и штампи водећих европских држава. Да некњижевни текстови нису просто „неутралне транскрипције реалности", показују рубрике домаће и стране штампе и периодике. Наталији је додељен статус прототипа мајке који је тада имао потпуно аутономан и аутентичан новински живот. Иако је европска штампа налазила разумевање за владарку-мајку која је протерана из Србије, било је и опречних ставова. Као русофил, краљица Наталија приказана је са много више грубости у односу на краља Милана, нпр. у бечком листу „Фигаро” / „Figaro” $(1889 / 1891)$.

Начин на који је краљ Милан извршио развод брака био је „нов доказ о његовој необузданој нарави и ћуди" (Јовановић, 2005: 441). Тако су се и најчешће теме домаће штампе односиле на Миланову омраженост од стране Радикала, карикатуре на рачун краљевог карактера и бројних атентата на њега. Осећала се огорченост на све видове тираније, од политичке па до културне, у времену последњих Обреновића ${ }^{13}$. Мађарски листови (Üstökös и Borsszem Jankó $)^{14}$ предњачили су у исцрпном извештавању о разводу краљевског пара, о напуштању Србије или повратку у њу, увек под скандалозним околностима. Притом, Миланово напуштање Србије због новца и забаве много је драстичније приказано у односу на Наталијино удаљавање, а потом враћање у Србију. Управо су публицистички прилози доказ колико се актуелна политичка ситуација и периодика прожимају и не могу једна без друге.

Представа о краљици као жртви која је током бракоразводне парнице креирана у јавности била је у оштром контрасту са сликом краљице као политички амбициозне жене како су је видели поједини савременици, али и британска штампа. Томе у прилог иде следећи цитат:

„Енергична, упорна и неретко непопустљива у својим ставовима и принципима, краљица-мајка Наталија временом је младом краљу и делу политичке елите постала оптерећење које је требало елиминисати" (...) Ма какве да су погрешке Краља Милана, он је показао мудрост абдицирајући на свој престо пре 2. године, а што је сада драговољно напустио земљу, он је радио у најбољем интересу за династију Обреновића. Краљица, пак, поткопавала је престо свога сина, и њено присуство у земљи није се могло дуже трпети" (Ристић, 2016: 16-21).

\footnotetext{
${ }^{13}$ Видети српске хумористично-саркастичне часописе који су се бавили политичким темама за време апсолутистичког обреновићевског режима: „Врач погађач”, „Геџа”, „Бич”, „Брка”, „Зврчка" итд.

${ }_{14}$ Ágnes Tamás, „Names of Characters of Non-Hungarian National Groups in Hungarian and Austrian Humour Magazines in the second half of the 19th Century". 2011 http://www.gencat.cat/ llengua/BTPL/ICOS2011/179.pdf (сајт консултован 12.02.2021.)
} 
Некадашњи краљев лични лекар, повереник и пријатељ, Владан Ђорђевић посветио је неколико дела из дворског живота породици Обреновић: роман Голгота. Силазак са престола. Роман из балканског живота (1909), роман У фронт (1913) и Успомене (1927). Због књиге Крај једне династије (1905-1906) Ђорђевић је био оптужен да је одавао државне тајне и завршио је у затвору.

Владан Ђорђевић је у роману Голгота прикрио идентитет краљице Наталије и краља Милана. Главни ликови су заправо Краљица Јерина (Наталија) и краљ Емилијан IV (Милан). Аутор се послужио паралитерарним дискурсом који обилује алегоријама пружајући искривљену слику дословне стварности. Патње краљице Наталије, која не жели да остане без свога сина, постају ефектније због њеног маскирања у лик Проклете Јерине која је у српском народном предању опевана као негативан лик безосећајне мајке и сурове владарке. Ево на који начин тим поводом Ђорђевић баца сенку на милосрдну појаву краљице Наталије:

„Нетрпељивост према краљици Наталији јасно се очитава и у роману Голго$m a$. Иако се не налази међу јунацима романа, њен дух је присутан - и у мислима младог Александра и у разговорима министара, али пре свега у Милановој исповести о животу без љубави и топлине, поред краљице охоле, горде и неосетљиве „санте леда”, ,јадне, дивне, лепе жена без срца, заљубљене у своју лепоту” (Костић, 2019: 461).

Истом техником послужио се аутор у књизи $У$ фронт који представља својеврсни наставак претходног романа и у коме се такође определио да преименује ликове (краљица Наталија је Јерина, „проклета Јерина”, док је краљ Милан поново Емилијан, у Паризу познат и као „гроф од Бруснице”). Роман прати живот краља Милана након напуштања престола и пресељења у Париз.

\section{Однос Србије са Румунијом у време владавине Милана Обреновића}

Важан садржај националне политике био је свакако однос Србије са Румунијом и румунским краљевским двором за време владавине Милана Обреновића која је трајала рачунајући и период његовог малолетства 21 годину.

Један од конкретних резултата за време владавине Милана Обреновића био је стицање независности 1878. године, након чега је уследио интензиван рад на модернизацији Србије. Конгрес у Берлину изазвао је промене у спољној политици Србије. Разочаран у руску дипломатију на Балкану, кнез Милан се окренуо Бечу. На трагу Румуније која је проглашена за краљевину 
14. марта 1881. године (Самарџић, 2007: 40) ${ }^{15}$ постигнут је договор са владом у Бечу, тако да је Аустроугарска пристала на идентичан корак Србије. Већ наредне 1882. године дошло је до међународног признања Србије за краљевину. Кнез Милан постао је „краљ Милан Обреновић IV”, а Наталија као прва нововековна српска краљица важна политичка фигура која је давала садржај националној историји у другој половини 19. и почетком 20. века.

Румунски принц Карол I (Carol I), био је одушевљен кнезом Миланом који га је 1874. године посетио у Букурешту. Велики румунски историчар Николај Јорга (Nicolae Iorga) забележио је детаље ове посете. Том приликом је Милан добио одликовање од принца Карола I. У униформи румунског пуковника „са сузама у очима и подрхтавањем у гласу” кнез Милан изговорио је здравицу на румунском језику упућену „племенитом витезу и брату” принцу Каролу I и принцези Елизабети (Elisabeta) ${ }^{16}$ : „Reinnoiesc cu acest prilej mulțumirile mele cele mai calduroase pentru Suveranul vostru și strig Să traiască bunul mieu frate Principele Carol! Sa traiasca Elisaveta Doamna! Sa traiasca Romania"17 (Iorga, 1916: 111-112). По оцени Карола I, Милан је био врло пријатне спољашности. Имао је урођену интелигенцију, али се видно осећао недостатак високог образовања и опште културе (Iorga, 1916: 188).

Наредне године, 1875. на церемонији венчања Милана и Наталије у Београду, Румунију је представљао генерал Николај Лупу (Nicolae Lupu) који се потом вратио у Букурешт уручивши писмо кнеза Милана упућено принцу Каролу, поводом овог догађаја (Milin, 1992: 100).

Миланову посету Букурешту краљ Карол I узвратио је 1884. године доласком у Србију и том приликом је краљица Наталија у својим Мемоарима записала следеће: „Румунски краљ је примљен у Београду као још нико дотад и био је очаран” (Н. Обреновић, 2006: 137).

Забележена је још једна посета Милана Обреновића Букурешту у првој половини јуна 1877. године када је боравио у гостима код свог ујака Ласкара Катарџија (Lascăr Catargiu) који је са руским званичницима договорио Миланов сусрет са руским царем у граду Плојешти (16-28 јун 1877). Како је забележено, пријем код руског цара у Плојештију био је прилично „хладан" (Catana, 2013: 25). У Мемоарима Краља Карола I наговештено је да је „својим доласком у Румунију кнез Милан креирао невоље” (Iorga, 1916:

${ }^{15}$ У припремама за проглашавање краљевина Румуније и Србије значајну улогу одиграли су: Председник румунске владе Јон Брацијану (Ion Brațianu), са румунске стране; Јован Ристић подржавао је „идеју да Србија треба да прати кораке Румуније, односно да и српски кнез треба да узме титулу „Краљевско Височанство” (Самарџић, 2007: 40).

${ }^{16}$ Оно што је Елизабету издвајало од многих европских краљица биле су њене уметничке склоности, нарочито оне које су се односиле на књижевност. Кармен Силва (Carmen Sylva / Cântul pădurii) био је литерарни псеудоним краљице Елизабете.

17 „Овом приликом изражавам најтоплију захвалност вашем Владару уз речи: Живео мој добри брат Принц Карол! Живела владарка Елизабета! Живела Румунија!” (Iorga, 1916: 111112). 
188). Карол I није био одушевљен Милановим присуством у Румунији вероватно због чињенице што је дошао у незгодном тренутку када се земља суочавала са руским одбијањем румунског предлога за војну сарадњу (рускотурски рат). Овај Миланов долазак у Румунију спомиње се и у Успоменама краљице Наталије у контексту заједничке акције са Русијом и његовим сусретом са руским царем о којем се, према речима Наталије Обреновић, кнез Милан ипак није негативно изјаснио:

„Господин Ристић га је пратио на том путу и нећу никад заборавити његову погруженост и узнемирење, које није успевао да прикрије, пред предстојећим пријемом с обзиром на лош глас који је уживао код руске владе”. (...) „Милан се вратио из Плојештија прилично задовољан, мада ништа одређено није закључено" (Обреновић, Н. 2006: 87).

Квалитету и динамици румунско-српских односа допринела је у великој мери краљица Наталија. Она је успела да остави леп утисак код краља Карола I и краљице Елизабете и како тврде румунски извори „имала је значајне сусрете на румунском двору у току владавине Милана Обреновића (Catana, 2013: 22).

Забележено је да су током свог боравка у Букурешту, принц Милан, принцеза Наталија и њихов син Александар били чести гости једног од најпрестижнијих боемских локала румунске елите онога времена - „Casa Capşa" (Ioniţă, 1997: 35) који постоји и данас.

Упоређивањем стандардних навода српских историчара и румунских извора примећено је да нема солидне основе за неке доскорашње тврдње о Наталијином руском пореклу. Бројни су записи следеће садржине: „Наталија је пореклом Рускиња” (Рајић, 2013: 251), „Наталија је пола-Рускиња” (Трговчевић, 2006: 24), „Наталијин отац је био из Русије” (Јовановић, 1934: 427), па чак „Наталија је рођена Рускиња” (Драговић, 2017: 318). Познавајући политичку климу у Србији, на заседању Народне скупштине Србије 1875. године, кнез Милан Обреновић је на следећи начин саопштио вест о својој женидби:

„Радујем се што вам могу навести догађај који једнако годи и Мом срцу и мојој владалачкој дужности. Као потомак оне лозе за коју је народ српски свагда засведочавао своју оданост мислим да сам, испуњавајући своју личну жељу, изашао у сусрет и народној, одабравши себи за другарицу у животу и на престолу своме Наталију Петровну из суплеменог нам народа руског, за који нас вежу и везе вере и крви и многобројне драгоцене успомене прошлости” (Милић, 2006: 183).

Тврдње о Наталијином руском пореклу носе извесну дозу традиционалне уопштености, а понекад и стереотипних закључака о српско-руским односима. Процеси преиспитивања не крећу се само унутар затворених научних кругова појединих дисциплина (књижевности, историје), већ су део јавног говора, политичке културе и конструисане историјске свести. Ова је 
свест донекле била уграђена и странцима који су боравили у Београду и били савременици дешавања на српском двору:

„Упола Рускиња, упола Румунка, Наталија по свом пореклу свакако припада двема земљама у којима је жена одавно ослобођена источњачког гинецеума. Пријеми које је она завела у салонима Конака учиниће мало-помало да српске госпође упознају чари овог пријатног живота за који Београђани нису скоро уопште знали за претходне владавине” (...) „Бој ће свакако поћи за руком да својим поданицима пружи приближну слику друштвеног живота какав се води у Петрограду и у Букурешту, да их научи оној вештини примања којој човек може да не буде вичан и кад најсрдачније испуњава дужности гостопримства” (Léger, 1967: 118-119).

У румунској историографији нема много нејасноћа о пореклу краљице Наталије, што потврђују експлицитни наводи, како традиционалних историчара попут Николаја Јорге, тако и савремених историчара:

„У Србији се није много говорило о Наталијином пореклу из Румуније, већ се на њу гледало кроз истицање руског порекла, што уопште није тачно ако узмемо у обзир да су оба њена родитеља потицала из Румуније. Наталијин отац, који је заиста имао јаке везе са Русијом, умро је када је Наталија имала само 6 година. Осим тога, њена мајка, која је била болешљиве природе, врло кратко време је живела у Русији. Дакле, од малих ногу о Наталији су се бринуле бака по мајци и тетке, које су пореклом такође из старих молдавских бојарских породица" (Catana, 2013: 22).

Као што је Милан Обреновић био Румун по мајчиној линији, из породице Катарџи (Catargiu) из Јашија, судбина је удесила да је и Наталија била Румунка по својој мами Пулхерији (Pulcheria Sturdza) из чувене румунске породице Стурдза (Sturdza), такође из Јашија (Iorga, 1916: 66 /115-116). Тако је и њихов син Александар, последњи Обреновић, имао рођаке у Јашију и био у сродству са бојарима Молдове преко породица Катарџи (Catargiu) и Стурдза (Sturdza). Румунски историографи сагласни су такође да је Наталијин отац, Петар Кешко (Кеșco) пореклом из Басарабије, био пуковник у руској војсци. Стара молдавска фамилија Кешко (Кеşсо) након освајања Басарабије 1812. године, добила је титулу руске племићке породице" (Lecca, 2000: 289). Завређује пажње да се укаже на чињеницу да је Наталија била рођака чувене румунске породице кнежева Гика (Ghica).

Наталија Обреновић, рођена је у Фиренци 14. маја 1859. године. Рано је остала сироче и бригу о њој преузели су рођаци из кнежевске породице Моруци (Moruzzi). Принц Константин Моруци (Constantin Moruzzi) и његова супруга, принцеза Катинка (Catinca) су бринули о њој. Своје детињство Наталија је провела на породичном имању у Басарабији у месту Бужор (Bujor) у Молдавији, а затим у конаку Дануцени (Dănuțeni) на обали реке Прут. Значајан период детињства провела је код своје баке Маргиолице Разновеану (Marghiolița RosettiRoznoveanu) у Јашију. Једно време боравила је у Одеси (Odesa) где су сахрањени и њени родитељи. Али, свакако од судбоносног значаја је њен боравак у Бечу где је упознала свог будућег супруга, кнеза Милана Обреновића. 
Извори српске и румунске историографије сагласни су у тврдњи да су Милан и Наталија били рођаци. По запису српског историчара Радоша Љушића, били су „друга братучад”. Родитељи кнеза Милана и кнегиње Наталије били су деца од две рођене сестре” (Љушић, 2001: 171).

„Нема сумње да су се Милан и Наталија венчали из љубави. Обоје су били маркантне појаве. И личили су међусобно на први поглед, што не треба да чуди јер су били рођаци: имали су заједничког прадеду. Да ли овој нечистој крви треба приписати мане њиховог сина Александра? Или пре можда инцестуозну страст која их је распалила? Обоје? Њихов брак је требало да буде утеха и надокнада за ломове у детињству, а постао је страст нечисте крви” (Stefanović, 2017: 67).

Историчар Слободан Јовановић објашњава „влашке црте карактера Милана Обреновића" (Јовановић, 1934: 271) пореклом његових родитеља. Милан се родио у градићу Марашешти (Mărășești) у близини града Јаши на имању своје мајке у време када се династија Обреновић налазила у прогонству (1839-1859) из Србије. Миланов отац, Милош Обреновић (1829-1860), био је син господара Јеврема, рођеног брата кнеза Милоша Обреновића. На Милановом крштењу кумовао је сам кнез Милош који му је дао име по свом брату, чувеном војводи рудничком и по свом најстаријем сину који је млад умро. Отац Милана Обреновића служио је као официр у румунској војсци и у време његовог рођења службовао је као капетан у градићу Марашешти. Погинуо је у борби са Турцима у близини Букурешта. Након погибије његовог оца, бригу о младом Милану преузео је рођак, Михаило Обреновић. О Милановом оцу Слободан Јовановић написао је да је живео неуредно и неверно: „коцкао се, јурио за женама и био распикућа. Много моралног осећања није имао, залагао је накит своје жене да би се могао проводити са другим женама, и није тражио од своје жене да му буде верна” (...) ,За разлику од кнеза Милоша и кнеза Михаила, Милан није био богат. Од оца му је остало само једно имање у Влашкој и то презадужено" (Јовановић, 1934: 301). Након убиства Михаила Обреновића III, 1868. године, о коме су написана бројна књижевноисторијска дела ${ }^{18}$, малолетни Милан је са само четрнаест година проглашен за кнеза Србије.

${ }_{18}$ Династија Обреновића владала је Србијом укупно 72 године. Конкретно, Кнез Михаило Обреновић (1823-1868) владао је Кнежевином Србијом у два наврата (1839-1842. и 18601868). У значајне доприносе који припадају тематском кругу о Обреновићима убрајамо рукописе драмског ствараоца, песника, критичара и историчара Ђорђа Малетића (18181888 ) који са посебним пијететом пише о кнезу Михаилу Обреновићу: Посмртна слава кнеза Мијаила М. Обреновића III „слика из народног живота с певањем” (1869), Спев юеговој светлости, милостивејшему господару и књазу србском Михаилу Обреновићу, Чувствованиє србскогъ народа о доласку М. Обреновића (1860), Химна приликом повратка из Цариграда светлога господара, кнеза Михаила М. Обреновића (1867). Незаобилазна грађа за свестраније упознавање владарске личности Михаила Обреновића представљају: драма Кнез Михаило, затим Бездно (1995) ауторке Светлане Велмар Јанковић, историјски романи Кнез Михаило, а затим и Милан Обреновић, аутора Душана Баранина; Убише књаза, аутора Живорада Лазића; Смрт кнеза Михајла (1893) Прогонство Обреновића (1896); Подсећамо да је Ђура Јакшић песмом На гробу кнеза Михаила глорификовао лик кнеза Михаила Обреновића. 
Мајка Милана Обреновића, Марија Елена Катарџи (Maria Elena Catargiu $)^{19}$, припадала је румунској аристократији. Била је пореклом из Молдавије. Њени родитељи били су: Костин Катарџи (Costin Catargiu) и Смаранда Балш (Smaranda Balş). Развела се од Милановог оца 1855. године и било joj је забрањено да прати одрастање сина Милана. Милан никада није успео да премости подвојеност која је постојала у односу са његовом мајком. Ова подвојеност од кључне је важности за формирање Милановог карактера. И Наталија је за нарав свога супруга често кривила Миланову мајку.

Миланова бака помиње се у књизи Ружа и трње у контексту Миланове изненадне одлуке да након посете бугарском кнезу у Рушчуку (данашње Русе) 1882. године, оде у Букурешт са жељом да је посети јер је била на самрти. Ту се једном реченицом открива колико се Милан „обрадовао што је опет међу својима, да није ни помишљао на враћање у Србију”. Ево како је у својим Мемоарима Наталија описала карактер свог мужа:

„Интелигентан и лукав, али без суштине под блиставом спољашношћу, размажен, сумњичаве и лажљиве нарави, склон заповедању, али неспособан да наметне своју вољу, док је његова истрајност у одабраном понашању била више тврдоглавост него ма шта друго. Уз то неваспитан, груб и сурово себичан, слабог карактера, подложан ласкању и женском утицају [...] не изгледа зао, али је способан да учини зло из подозрења. Презире људе и неспособан је да поверује у племенита осећања и оданост [...] Снисходљив пред вишима, дрзак према нижима, недовршена природа, несрећна за себе и неспособна да пружи срећу другима. Заиста достојан сажаљења. То је Милан” (Обреновић, H., 1999: 112-113).

У Милановом владарском веку догодиле су се многе турбуленције: политичке, друштвене и оне које се односе на приватан краљев живот. По Јовановићу „Милан је био нарцисоидан и сујетан, осион, подозрив, плаховит, без икаквих позитивних емоција. Али и паметан и прорачунат и немилосрдан, рибар и трговац људским душама. Живео је расипно и разуздано. Тако је и владао" (Јовановић, 2005: 94-97). Из угла посматрача са стране, краљ Милан умео је да приреди сјајне гозбе и зачини разговором пуним хумора дворске свечаности на којима је Наталија, „лепа, витка жена, играјући и сама, радо остајала често до зоре” (Kanitz, 1967: 285).

Миланову немоћ да обузда страсти пред „лепим, духовитим, страсним и врло амбициозним младим удовицама" потврђује неколико извора. Миланова афера са његовом сестром од ујака Маријом Катарџи, која је била штићеница на београдском двору 1884. године допринела је заоштра-

\footnotetext{
${ }^{19}$ Марија Елена Катарџи (1835-1876) била је позната због љубавне везе коју је дуго имала са владаром Уједињене Румуније, Александром Кузом (Alexandru Ioan Cuza). Да би му била ближа, Александар Јон Куза купио је Марији кућу у Букурешту (у улици Амзеј, бр. 3) где је често проводио време са њом. Марија је румунском владару родила два сина: Александра и Димитрија, које је он законски признао, у договору са својом супругом Еленом Розети (Elena Rosetti) са којом није имао деце.
} 
вању брачних односа Наталије и Милана. Непрестане политичке и брачне несугласице, нарочито 1884. и 1885. године су Милана „нервно истрошиле". Вест о Милановим љубавним аферама стизале су преко Лондона до Букурешта до румунског краља Карола I: „Краљев однос са ћерком генерала Катарџи, дворском дамом краљице, била је позната афера у Београду, будући да краљ и његова љубавница нису могли обуздати погледе за столом" (Lukács' 1884: 86).

У Успоменама је Владан Ђорђевић потврдио да је захваљујући дугогодишњој сарадњи с краљем Миланом могао да дочара сву сложеност карактера српског владара. Аутор даје приказ Миланових авантура: најпре са удовицом Лепосавом Новаковић због које је био спреман само три године након ступања на престо да побегне у Румунију и „служи у шестом пуку влашке пешадије, да буде свој човек и да се ожени онако како му је срцу драго", а затим са Мицом Протић - дворском дамом, женом генерала Косте Протића, кнежевог верног сарадника.

Највише трага, међутим, оставила је Миланова афера са Артемизом Христић, Гркињом из Цариграда са којом је имао непризнатог сина Ђорђа (Stefanović, 2017: 73). У својим настојањима да постане законита жена краља Милана, Артемиза је напустила свога мужа. Када је остала трудна, уцењивала је краља и прогонила га, не размишљајући о последицама ни о томе да ли је уопште дорасла да буде на престолу. Владан Ђорђевић се у поменутом роману Голгота, послужио иронијом те је ову краљеву љубавницу насликао као одговорну, савесну и образовану жену што Артемиза Христић свакако није била. Романсу под називом Љубавна прича о дону Нунешу и дона Клари, Војислав Илић посветио је управо овом љубавничком односу.

Било да су у питању оде у славу краљице или краља, или пак писање у „непријатељском духу” уперено против српског краљевског дома ${ }^{20}$ сложићемо се да је репертоар посвећен овој владарској породици разноврстан. Отуда су аутори у својој поезији, прози или драми често градили субјективну истину, неподударну са историјском истином, намењену одређеном преломном историјском тренутку српске нације. Понекад су стављали књижевност у неки периферни план те је она била у функцији диктата историјске стварности.

Од великог књижевноисторијског значаја су историјске драме посвећене овој владарској породици: Силазак с престола (1941) аутора Ранка Младеновића и Конак (1958) аутора Милоша Црњанског. Затим, пажње су вредне политичке сатире Радоја Домановића (Страдија, Вођа, Данга, Мртво море, Укидање страсти) настале у неколико последњих година обреновићевског апсолутизма, између 1889. и 1903. године. О стању унутар

\footnotetext{
20 Због песме Погреб два раба Бранислав Нушић осуђен је на две године робије јер је увредио краља Милана. Због песме На прекор другу Стев. Сремиу, у којој се аутор жали на време у којем живи, против Драгутина Илића је 1900. спроведен судски поступак.
} 
владарске породице Обреновића и о оновременим културним, политичким и друштвеним збивањима у краљевини Србији, послужила су нам и публицистички текстови Лазе Костића ${ }^{21}$. Интегрисање документарне прозе у канонске токове српске књижевности наставља се и данас па тако издвајамо лирску приповест Страст нечисте крви (2017), аутора Ненада Новака Стефановића.

Поменуте текстове осим теме, повезују: исповедни дискурс, колебање између документарности и литерарности, нефикционалности и фикционалности, али и „условљеност дела друштвеним околностима и колективном друштвеном енергијом" (Greenblatt, 2003: 42).

Путеви које пролази краљица Наталија у функцији су осликавања једног друштвеног и државног уређења које се рефлектује на плану политичког и културолошког нивоа тадашње Србије. Наталија Обреновић није желела да пристане на Миланов захтев да сина виђа једном годишње у неком од страних летовалишта, како је предложио краљ након развода. Миланов циљ био је да краљица Наталија напусти земљу, те да нема директног утицаја на малолетног сина. Наталија, међутим, није намеравала да попусти јер је као мајка сматрала да је њен син лоше васпитаван.Осим тога, противила се идеји свог супруга да се њихов син Александар васпитава у Бечу.

Након што се настанила у Визбадену са Александром, краљица Наталија и њено дете постали су жртве политичких скандала. По жељи краља Милана и његове владе и немачке полиције, краљевић је отет од мајке и одведен у Београд. Овај догађај приближио је њен савременик Драгутин Илић у Успоменама из Румуније „из бележника емигранчевог” (1904/1905). Драматичне догађаје из српске историје Илић ставља у раван јаких литерарног исказа:

„У то време пуче глас о Висбаденском догађају - отмици српскога престоло-
наследника из руку мајчиних. Српска и бугарска емиграција, па и сами Руму-
ни у Турну Северину, беху толико узрујани овом отмицом, која беше на онако
недостојан и дивљачки начин извшшена, да се тих дана ни о чему другом
није говорило већ само о несретној мајци којој отимљу дете. До тога времена
краљицу Наталију сваки је жалио као честиту жену, која не беше ни издалека
налик оним госпођама на трону, које се, после краће или дуже душевне борбе,
мире са својом брачном судбином и у складу живе са својим крунисаним су-
пругом, задовољавајући се сујетом круне и ... Она не имађаше снаге за то те,
борећи се за своја брачна права, изгуби и мужа и круну, али очува једно, што
јој чак ни њезин највећи непријатељ, краљ Милан, није могао порећи. После
Висбаденскога догађаја краљица доби име: мајка - мученица. Људи од срца и
душе отворено су изјављивали своју грозу према краљу - нечовеку; они исти
Румуни у Турну Северину, који су после 29 . маја тукли и пребијали Србе, да
би осветили смрт краља Александра и Драге, и који су тих дана величали име

${ }^{21}$ Видети: Лаза Костић, О политици; О уметности: новински чланции. 4, 1887-1891, 1903, Нови Сад 1990. 
краља Милана и рођакали се њиме, тада су јавно говорили, како су Срби кукавички народ кад трпе на престолу ,једног Нерона” који је упропастио своју кућу, па сада и државу” (Илић, 1904: 341).

Врло је убедљиво писала румунска штампа о епизодама након развода брака Милана и Наталије. Наталија се вратила у Јаши код своје баке Маргиолице Разновеану (Marghiolița Rosetti-Roznoveanu) из Станке (Stânca), која је уједно била прабака малог Саше Обреновића. Тим поводом цео град Јаши изашао је на железничку станицу да дочека Наталију и њеног сина Сашу којег је носила у наручју. „Са бројним познаницима и рођацима упутила се према палати породице Разновеану у улици Стефана Великог у Јашију”, писала је румунска штампа 1938. године, још за живота Наталије Обреновић. У истом чланку наводи се да је краљица Наталија живела неко време у Румунији: у градовима Јаши, Букурешт и Станка (Raşcanu, 1938: 7).

Дугогодишња борба око развода и политичке размирице Милана и Наталије пољуљале су углед српског престола и династије, али и оставиле трајне последице на њиховог сина Александра. Ђорђе Генчић преноси разговор са краљем Александром Обреновићем који у свом одрастању праћеном осећајем празнине замера родитељима због развода:

„Да много не говорим о моме детињству. Ви знате да га ја нисам ни имао и да сам благодарећи разводу између мојих родитеља био лишен сваке радости и милоште родитељске у детињству. Прилике у којима сам живио од раног детињства мог па до сада, тако су чемерне и тешке биле, да су оне оставиле неизгладив траг и на душу и на срце моје које је очврстало. Осећаји нежне љубави према родитељима мојим давно су ишчилели, јер моји родитељи немађаху ни трунке љубави за мене. Њихова узајамна мржња беше јача од љубави родитељске. Та мржња беше извор свемогућих домаћих несрећа, по среди којих стајах ја, не знајући куда и на коју ћу страну. Покадшто мислих да ћу полудети, јер око мене никада не беше који би ме прихватио и пригрлио, који би ми реч утехе рекао” (Крестић, 2018: 71).

Наталија ће се након четири године од протеривања из Србије вратити у Београд спремна на нови обрачун са Миланом. Била је одлучна у намери да активно помогне свом сину у вођењу државне политике. Услед тога дошло је до несугласица између ње и Александра.

„Наталија је била жена високог, можда и претераног самопоштовања, али и јаких страсти. Исто онако како је најпре волела, а потом мрзела мужа, тако се растала и са сином. Љубав према њему надвладана је осећањем срама, увређеност због његових поступака је потиснула нежност, сујета је била јача од потребе да буде уз њега" (Трговчевић, 2006: 31).

Раскораку мајке и сина, међутим, највише је допринео Александров избор Драге за будућу краљицу.

„Ја знам да родитељи моји женидбу са Драгом не одобравају, да јој се срцем противе. Ја искрено патим због тога и несрећан сам што су односи између 
мојих родитеља и мене поремећени и срцем својим желим да се они поново доведу у склад. Јасно је мени да је у интересу династије да се са својим родитељима измирим. Али моји родитељи условљавају измирење са мном мојим разводом са Драгом" (Милић, 2006: 231).

Старија 10 година од Александра, Драга је била одлучна у намери да прекорачи границе своје класне позиције и класног идентитета. У колективном сећању, махом и у литератури, Драга је остала упамћена као ограничавајући и узнемирујући фактор монархије.

Милош Црњански у драми Конак настоји да у фикционом контексту, не спомињући директно краљицу Наталију, одјекну историјска егзактност и драматичност догађаја који су емотивно ломили краљицу. Радња се одвија у двору у Београду и у Бијарцу. Сликајући раскол унутар личности на линији приватни/јавни живот, аутор пише о љубави и трагичној смрти Наталијиног сина, краља Александра Обреновића. Црњански је конципирао лик са акцентом управо на несређене односе оца и сина, али и мајке и сина. У драми је краљица Драга осликана као један од главних фактора који је допринео гашењу династије Обреновић. У средишту пажње су преламања у књижевном лику Александра Обреновића, његове борбе и напуклине, као и начин на који оне утичу на његову судбину. Александрова женидба са бившом дворском дамом краљице Наталије, али и обесно понашање Драгине браће изазвали су климу која је довела до свирепог убиства краљице Драге и краља Александра (у 27. години живота) 29. маја 1903. године. О овом немилом догађају писао је и Драгутин Илић у Роману краљиие Наталије: Одломии из дневника. Без потомства, династија Обреновића била је осуђена на нестанак.

Крвавом исходу, према наводу Сузане Рајић, претходиће упозорење краљу Александру са румунског двора од стране краља Карола I: „Упозорење је добио од своје тетке Маврокордат, сестре краљице Наталије која је упозоравајућу поруку послала на изричит налог румунског краља Карола, затим од бугарског кнеза Фердинанда, али и руске тајне службе” (Рајић, 2011: 487).

После Мајског преврата 1903. и убиства сина, Наталија је живела у манастиру Сионске Богородице у Француској. У овом контексту вредно је поменути и телевизијску драму насловљену Крај династије Обреновић, али и један од првих филмова који је рађен на основу новинарских извештаја, настао непосредно након Мајског преврата - Убиство српске краљевске породиие.

Поремећени породични односи „краља, краљице и престолонаследника" су у средишту драме, Силазак с престола (1941), аутора Ранка Младеновића. Аутор је дочарао опште незадовољство народа, изазвано краљевим подношењем захтева за развод брака. У драми се инсистира на Наталијиној изванредној лепоти и омиљености у народу. То је још једна потврда да зна- 
чење књижевног дела није резултат пишчеве личне намере, већ је резултат контекстуалних асоцијативних веза које симболи једног дела успостављају са укупном симболиком књижевне традиције.

Као јунак Романа о краљици Наталији, Драгутин Илић размишља о могућим разлозима за Александрову извитоперену личност и приписује је пре свега недостатку мајчинске фигуре и дисфункционалној породици којом је управљала политика. Наталијин идентитет у драми Конак откривамо кроз епизоду у којој Александар разговара са мајчином сликом. Из лирске реплике краља Александра сазнајемо да је Наталија поражена непослушношћу свога сина и због тога напушта православље:

„Гледам ову слику, коју ми је татап послала. Како ме чудно гледају њене очи. Пише ми, да је због тебе, прешла у католичку веру. Неће са нама ни у исту цркву. Сад сам јој ја крив што са мужем није била срећна у животу. Како ме те очи прате. Ви сте при вечери пили шампањ, ја нисам... Да сам пио, мислио бих да сам цврцнуо ... Nom de Dieu... Како ме те очи гледају (...) Шта сам се подетињио... Joujou! Joujou... Ходи овамо... МОГАО БИХ СЕ ЗАКЛЕТИ да видим сузе у материном оку... да плачу... “(Црњански, 1985: 330).

Прави разлог преласка у католичанство „лежао је у повређивању прекомерне женске сујете, што је краљицу побудило на чин који је изазвао осуду друштва и штампе. Преверавањем краљица Наталија је покидала све везе не само са православном црквом, већ и са Русијом, исказујући доста дуго пре тог чина неразумевање и неслагање са руском политиком према Србији, а напосе према њој лично. Висока политика је за њу била само прљава игра, у којој је Русија окаљала свој образ” (Рајић, 2013: 251).

\section{Закључне напомене}

Бројне су приповедне творевине и историјске драме посвећене краљици Наталији и краљу Милану које отварају културу сећања и интертекстуалних релација српске и румунске књижевности, историје и уметности. Битно је нагласити да културна поетика није само пуко историјско контекстуализовање књижевног текста, већ се ради о узајамном прожимању књижевности и културе схваћеном као неисцрпан процес. Нови историзам књижевно дело дефинише као интегрисани део културе у акцији које чини мноштво гласова и прихвата га као чиниоца друштвено-историјске моћи, као поље борбе, као место сукоба које се јавља због незадовољства које је било усмерено ка књижевној историји.

Замисао нашег излагања односи се на неколико сегмената: реакцију на формалистички приступ књижевности, неопходност разбијања представа о строго одређеној зони књижевне продукције, преиспитивање конструкција о стабилном националном језгру, сламање граница између друштвене и при- 
ватне представе о Наталији, проблематизовање разлика између књижевног и политичког дискурса, схватање историје као текста о којем се „преговара” на пољу уметности, политике, културе и структура моћи, а затим и схватање историје као кретања и сталне смене вредности.

У том смислу су приметна извесна историјска неподударања, али и ситуације које су део неиспричане историје. Доминантна историографска линија приповедања која прати преломне тренутке у Наталијином животу: „руско” порекло, долазак на српски двор, рођење сина Александра, политичке размирице са супругом, Миланове љубавне афере, развод брака, прогон из Србије, сукоб са сином због избора супруге-краљице Драге, прелазак у католичанство у њеној 43.години живота, и најзад Мајски преврат 1903. године и убиство њеног сина, у литерарним делима и новинским чланцима каткад губи контакт са фактографијом.

На основу бројних извора, књижевних текстова, историјских чињеница који се односе на комплексан доживљај краљице Наталије и владавину династије Обреновића уопште, препустили смо се игри интерпретација, истраживања, имагинације и комбиновања. Посреди је флукс, кретање, размена, будући да се историја у многоме представила не више као откривање прошлости, већ као инвенција и креација, као својеврсно језичко обликовање прошлости.

Упуштајући се у ма коју упоредну анализу владарских личности Наталије и Милана Обреновића, важно је да установимо у којој мери су овакве структуре уједно неисцрпне и отворене, те се непрекидно могу допуњавати новим подацима. За нова књижевнокритичка читања дела била је потребна већа временска удаљеност и другачија поетичка и књижевнокритичка контекстуализација. Као решење, на место субјективности писца, треба да стане објективност читаоца. Другим речима, текстове који се односе на личности краљице Наталије и краља Милана Обреновића требало је осмотрити у спрези са сложеном структуром институција, праксе и веровања који су обликовали културу у којој су настајали.

Најзад, културно-историјске релације краља Милана и краљице Наталије Обреновић, као део укупних међусобних веза српске и румунске културе неизбежно чине неодвојиви део румунског идентитета.

\section{Литература}

Бужињска, Марковски, 2009: A. Bužinjska, M. P. Markovski, Književne teorije XX veka. Beograd: Službeni glasnik.

Вивијен, 1897: H.Vivian, М.А. (Херберт Вивијен), Servia, the poor man's paradise / Србија-рај сиромашног човека. (превела Мара Пандуровић), у Београд у деветнаестом веку. Београд: Библиотека града Београда, 1967. 149-180. 
Доћеа, 2007: Vasile Docea (превео текст са немачког језика), Jurnal Carol I al României/Дневник краља Карола првог од Румуније. Iași: Polirom

Драговић, 2017: М. Драговић, Наталија Обреновић: Из необјављене преписке прогнане краљиие, у Обреновићи у музејским и другим збиркама Србије и Eвропе V. Горњи Милановац: Музеј Рудничко-таковског краја.

Гринблат, 2003: S. Greenblatt, Kolanje društvene energije, Novi istorizam i kulturni materijalizam. Ka poetici kulture. Сомбор: Домети, 1-4, 108-111.

Херман, 2005: David Herman, Manfred Jahn and Marie-Laure Ryan, Routledge Encyclopedia of Narrative Theory, London and New York, Routledge.

Илић, 1904: Д. Илић, Успомене из Румуније. Босанска вила, бр. 19. / бр. 20, Сарајево: Српска дионичарска штампарија.

Илић, 1905: Д. Илић, Успомене из Румуније, у „Босанска вила”, Сарајево: Српска дионичарска штампарија.

Илић, 2015: Д. Илић, Роман краљиие Наталије (Приредила: Светлана Томић). Београд: Службени гласник.

Јовановић, 1934: С. Јовановић, Влада Милана Обреновића, I, II, III, Београд: Издавачко Предузеће Геца Кон.

Јовановић, 1990а: С. Јовановић, Влада Милана Обреновића. Део 2. Београд: БИГЗ

Јовановић, 1990б: С. Јовановић, Влада Александра Обреновића. Београд.

Јовановић, 2005: С. Јовановић, Портрети. Београд: Народна књига.

Јоница, 1997: M. Ioniţă, „O casă de comerţ bucureşteană - Casa Capșa - în competiţii interne şi internaţionale din a doua jumătate a secolului al XIX-lea”. Bucureşti: Muzeul Naţional de Istorie a României IX.

Јорга, 1914: N. Iorga, Pagini despre Serbia de azi. Bucureşti: Editura Casei Școalelor.

Јорга, 1916: N. Iorga, Politica externă a regelui Carol I. Bucureşti: Inst. De Arte Grafice CAROL GOBL.

Јopга, 1934: N. Iorga, O viață de om: Așa cum a fost. București: Ed. N. Stroila.

Каниц, 1904: Felix Kanitz (Феликс Филип Каниц), Das Konigreich Serbien und das Sebenvolk von der Romerzeit bis zur Gegenwart / Краљевина Србија и српски народ (превео професор Радослав Јанковић), у Београд у деветнаестом веку. Београд: Библиотека града Београда, 1967. 181-249.

Катана, 2013: B. Catana, Relații româno-sârbe 1875-1913, Scurt istoric al reprezentanţelor diplomatice de la Belgrad şi Bucureşti ale României şi respectiv Serbiei / Rumunsko-srpski odnosi 1875-1913, Kratak pregled diplomatskih predstavnika Beograda i Bukurešta, odnosno Rumunije i Srbije. Târgoviște: Ed. Cetatea de scaun.

Косановић, Туцаковић, 1998: Д. Косановић, Д. Туцаковић, Странцฺи у рају. Београд: Стубови културе.

Костић, 2018: Љ. Костић, Успомене на краља Милана у контексту мемоарске прозе Пере Тодоровића, у Зборник радова. Užice: Педагошки факултет у Ужицу, година 21, бр. 20 децембар. 
Костић, 2019: Љ. Костић, Краљ Милан у књижевном делу Владана Ђорђевића, у Зборник Матице српске. Нови Сад: Матица српска, 449-462.

Костић, 1990: Л. Костић, О политици; О уметности: новински чланци. 4, (18871891), 1903, Нови Сад.

Крестић, 2018: П. В. Крестић, Министар Генчић о женидби краља Александра Обреновића, у Зборник Матице српске за историју. Нови Сад: Матица српска, 67-79.

Лека, 2000: Octav-George Lecca, Familiile boiereşti române. Bucureşti: Libra/ Muzeul Literaturii Române.

Лежер, 1884: M. L. Léger (Лyj Леже), La Save, le Danube et le Balkan. Voyage chez les Slovenes, les Croates, les Serbes et les Bulgares / Сава, Дунав и Балкан, Paris, Librairie Plon, (превео Радослав Јанковић), у Београд у деветнаестом веку, из дела страних писаиа. Београд: Библиотека града Београда, 1967. 107-121.

Лукас, 2013: Antal Lukács, Raportul politic al arhiducelui Rudolf de Habsburg asupra călătoriei sale în Orientul european (Imperiul Otoman, Principatul Bulgariei, România şi Serbia) din anul 1884, y Caiete diplomatice. București: Institutul Diplomatic Român бp.1 https://www.idr.ro/publicatii/Caiete\%20Diplomatice.pdf (сајт консултован 11.02.2021.)

Љушић, 2001: Р. Љушић, Љубави српских владара и политичара. Београд: Народна књига/ Алфа.

Милин, 1992: M. Milin, Relaţii politice româno-sârbe în epoca modernă (secolul al XIX-lea). Bucureşti: Editura Academiei Române.

Милић, 2006: Д. Милић, Српски политички говор модерног доба. Београд: Службени гласник.

Милутиновић, 2007: Д. Милутиновић, Положај историје у интерпретацији књижевног текста, у Зборник Матице српске за књижевност. Нови Сад: Матица српска 409-420.

Обреновић, 1891: Н. Обреновић, „Мајка”, Une mère, Natalie, reine de Serbie, Le Petit journal, 1891, Numéro 28, превод са француског Сандра Трипковић, Горњи Милановац: „Слово Һирилово” 2015. http://www.bibliotekagm. com/wp-content/uploads/2017/12/Slovo-Cirilovo-12.pdf (сајт консултован 13.01.2021.)

Обреновић, 1999: Н. Обреновић, Моје успомене. Прев. Иванка Павловић, (приредила: Љубинка Трговчевић). Београд: Српска књижевна задруга.

Падуреан, 2020: Bianca Pădurean, Pagina de istorie: Povestea româncei Natalia Obrenovici, prima regină a Serbiei /Stranica istorije: Priča Rumunke Natalije Obrenović, prve kraljice Srbije, 15 maj, 2020. https://www.rfi.ro/politica-121186pagina-de-istorie-poveste-romanca-natalia-obrenovici-prima-regina-serbia (сајт консултован 10.01.2021.)

Перић: 1967, О. Перић, Београд у деветнаестом веку. Из дела страних писай (Приредила: Олга Перић). Београд: Београдски графички завод.

Раденић, 1973: A. Radenić, Progoni političkih protivnika u režimu Aleksandra Obrenovića 1893-1903. Beograd: Istorijski arhiv Beograda. 
Радонић, 1973: A. Radenić, Progoni političkih protivnika u režimu Aleksandra Obrenovića 1893-1903. Beograd: Istorijski arhiv Beograda.

Рајић, 2011: С. Рајић, Александар Обреновић, Владар на прелазу векова, сукобљени светови. Београд: Српска књижевна задруга.

Рајић, 2013: С. Рајић, Краљица Наталија и Русија - од развода до преверавања, у Српске студије, књ. бр. 4, Београд: Центар за српске студије, Филозофски факултет Универзитет у Београду.

Ранчић, 2010: V. Rančić, Konačna istina. Olga i Pavle Karađorđević između istine $i$ sudbine. Beograd: Dereta.

Рашкану, 1938: Th. Raşcanu, Ex-regina Nathalia a Serbiei n'a murit? - Amintiri ş1 lămuriri / Бивща краљиияа Србије Наталија није умрла? - Сећања и сведочанcmва, у Universul literar, anul XLVI I • Nr. 2, 9 Iulie, cтр. 7. http://dspace.bcucluj. ro/jspui/bitstream/123456789/18894/1/BCUCLUJ_FP_P3441_1938_047_0021. pdf (сајт консултован 3.01.2021.)

Ристић, 2016: Д. Ристић, Британска штампа о прогонству краљице Наталије из Србије 1891. године, у Историјске свеске, бр. 29. мај, стр. 16-21.

Самарџић, 2006: М. Самарџић, Његово Краљевско Височанство Кнез Милан, у Зборник Матице српске за историју. Нови Сад: Матица српска, 37-49.

Станојевић, 2005: М. Станојевић, Портрет народнога краља. Београд: Чигоја.

Станојевић, 2005: М. Станојевић, Деветсто трећа: књижевни погледи:Лаза Костић, Драгиша Васић, Слободан Јовановић, Црњански..., 136-148.

Стефановић, 2017: N. Stefanović Vodič kroz ljubavnu istoriju Beograda. Beograd: Laguna.

Тамаш, 2011: Á. Tamás, Names of Characters of Non-Hungarian National Groups in Hungarian and Austrian Humour Magazines in the second half of the 19th Century. http://www.gencat.cat/llengua/BTPL/ICOS2011/179.pdf (сајт консултован 12. 02. 2020.)

Тодоровић, 1997: П. Тодоровић, Српска ствар у Старој Србији: Успомене на краља Милана (приредила Латинка Перовић). Београд: Службени лист СРЈ.

Томић, 2015: С. Томић, Значај књижевних радова краљице Наталије, у: Наталија Обреновић, Ружа и трюе. Београд: Лагуна.

Трговчевић, 2006: Lj. Trgovčević, Kraljica Natalija Obrenović, Moje uspomene. Beograd: Srpska književna zadruga.

Црњански, 1985: М. Црњански, Конак, у Драме (Приредио: Светозар Марков). Букурешт: Издавачко предузеће „Критерион”.

Чубрић, 2012: Lj. Čubrić, Spomenar. Beograd: Zavod za udžbenike. 
Oktavija I. Nedelku

Lidija V. Čolević

\title{
WHEN I GROW UP I WILL BE A QUEEN: NATALIA AND MILAN OBRENOVIC
}

\begin{abstract}
Summary
On the trail of new historicism, understanding the relationship between historical and artistic reality, visual culture and art, historiographical and literary ideas about Queen Natalia Obrenovic, helps to stratify the great number of roles she played in Serbian culture.

The cultural-historical relations between King Milan and Queen Natalia Obrenovic, as part of the overall mutual ties between Serbian and Romanian culture, are indisputably an inseparable part of Romanian identity.

Key words: new historicism, fictional and historical characters, Queen Natalia Obrenović, King Milan Obrenović IV, King Alexander Obrenović, Romanian identity.
\end{abstract}

